\title{
TOKSISITAS DAN IMUNOGENISITAS PRODUK EKSTRASELULER Mycobacterium fortuitum PADA IKAN GURAME (Osphronemus gouramy)
}

\author{
Siti Fatimah" ${ }^{* \#}$, Agustin Indrawati"), dan Angela Mariana Lusiastuti" ${ }^{\left.{ }^{* * 4}\right)}$ \\ ") Direktorat Kesehatan Ikan dan Lingkungan, Direktorat Jenderal Perikanan Budidaya \\ ") Departemen Ilmu Penyakit Hewan, Fakultas Kedokteran Hewan, Institut Pertanian Bogor \\ malai Penelitian dan Pengembangan Budidaya Air Tawar
}

(Naskah diterima: 26 September 2014; Revisi final: 1 Desember 2014, Disetujui publikasi: 5 Juni 2015)

\begin{abstract}
ABSTRAK
Mycobacterium fortuitum merupakan bakteri patogen dengan kejadian penyakit bersifat kronis. Penelitian ini bertujuan untuk mengevaluasi tingkat toksisitas dan imunogenisitas produk ekstraseluler M. fortuitum pada ikan gurame. Pengujian toksisitas dilakukan pada ikan dengan bobot $15 \mathrm{~g}$ yang diinjeksi secara intraperitoneal (i.p) dengan konsentrasi ECP berbeda yaitu 7,15 $\mu \mathrm{g} / \mathrm{ikan} ; 14,3 \mu \mathrm{g} / \mathrm{ikan} ; 28,6 \mu \mathrm{g} / \mathrm{ikan} ; 57,2$ $\mu \mathrm{g} / \mathrm{ikan}$; sedangkan kontrol dengan menggunakan PBS. Pengujian imunogenisitas dilakukan dengan menggunakan ikan seberat 25-30 g. Ikan dibagi dalam tiga perlakuan yaitu: ECP dengan Freund Incomplete Adjuvant (FIA), ECP, dan kontrol (sauthon broth). Hasil yang diperoleh menunjukkan bahwa ECP M. fortuitum hingga konsentrasi 57,2 $\mu \mathrm{g}$ /ikan tidak toksik pada ikan gurame. Sementara, tingkat imunogenisitas menunjukkan bahwa ikan yang diinjeksi dengan ECP ditambah FIA dan ECP saja memiliki respons imun non-spesifik dan spesifik yang lebih tinggi dan berbeda nyata $(\mathrm{P}<0,05)$ dibandingkan dengan kontrol. Hal ini menunjukkan bahwa ECP $M$. fortuitum bersifat imunogenik pada ikan gurame sehingga berpotensi untuk dikembangkan sebagai vaksin guna penanggulangan mycobacteriosis.
\end{abstract}

KATA KUNCI: M. fortuitum, produk ekstraseluler, gurame

ABSTRACT: Toxicity and imunogenicity of extracellular product Mycobacterium fortuitum in giant gouramy (Osphronemus gouramy). By: Siti Fatimah, Agustin Indrawati, and Angela Mariana Lusiastuti

\begin{abstract}
Mycobacterium fortuitum is a pathogenic bacterium with a chronic disease course on giant gouramy. This study was aimed to evaluate the toxicity and immunogenicity of ECP M. fortuitum on giant gouramy. Toxicity assay was conducted using fish with a weight of $15 \mathrm{~g}$ and the ECP be divided into four concentrations i.e $7.15 \mu \mathrm{g} /$ fish, $14.3 \mu \mathrm{g} /$ fish, $28.6 \mu \mathrm{g} /$ fish, $57.2 \mu \mathrm{g} /$ fish, the controls used PBS. All of them was injected by intraperitoneal injection (i.p). Immunogenicity assay using fish with a weight of 25-30 g on three groups, i.e ECP in Freund's Incomplete Adjuvant emulsion (FIA), ECP and control (sauthon broth). The results indicated that the concentration of ECP up to $57.2 \mu \mathrm{g} /$ fish non toxic to giant gouramy. Meanwhile, immunogenicity assay showed that the fish was injected by ECP and ECP with FIA revealed specific and non-specific immunity that higher than the control. There were statistically significant differences $(P<0.05)$ between treatments with a control. This suggested that the ECP M. fortuitum was immunogenic on giant gouramy and can be used as one of the candidate vaccine for the prevention of mycobacteriosis.
\end{abstract}

KEYWORDS: M. fortutitum, extraceluller product, giant gouramy

\section{PENDAHULUAN}

Gurame (Osphronemus gouramy) adalah ikan asli Indonesia dan merupakan salah satu komoditas unggulan pada budidaya ikan air tawar. Sentra budidaya ikan gurame di Indonesia antara lain: di Jawa, Nusa

\# Korespondensi: Direktorat Jenderal Perikanan Budidaya. Gedung Menara 165, Lantai 15, Jl. T.B. Simatupang Kavling 1, Cilandak Timur, Jakarta Selatan 12560, Indonesia.

E-mail: fa_koe@yahoo.com
Tenggara Barat, dan Sumatera. Ikan gurame memiliki nilai ekonomi yang cukup tinggi, berukuran besar, dan berpotensi tumbuh cepat. Salah satu kendala yang dihadapi pada budidaya ikan gurame adalah adanya penyakit bakterial yang disebabkan oleh Mycobacterium spp.

Mycobacterium spp. merupakan bakteri intraseluler yang dapat hidup di dalam sel fagosit sehingga sulit untuk dieliminasi dari inang. Salah satu jenis Mycobacterium spp. yang ditemukan menginfeksi ikan 
gurame adalah $M$. fortuitum. Selain mampu menginfeksi ikan, Mycobacterium spp. juga mampu menginfeksi manusia (M. tuberculosis, M. leprae) dan hewan besar seperti sapi (M. avium subspecies paratuberculosis). Menurut Gauthier \& Rhodes (2009), Mycobacterium spp. yang sering ditemukan menginfeksi ikan antara lain: M. fortuitum, M. chelone, M. marinum. Keberadaan Mycobacterium spp. dapat ditemukan di tanah, debu, batu, dan air. Mycobacterium spp. selain menginfeksi ikan gurame (Rukmono, 2003), juga dapat menginfeksi ikan air laut maupun air tawar lainnya seperti ikan kakap (Bozzetta et al., 2010), bandeng (Chang et al., 2006), salmon (Bracklebank et al., 2003) dan ikan hias (Zanoni et al., 2008).

Penyakit yang disebabkan oleh bakteri Mycobacterium spp. dikenal dengan mycobacteriosis dan bersifat kronis progresif (Decostere et al., 2004). Pada ikan gurame kematian akibat penyakit tersebut berkisar antara 30\%-60\% (Rukmono, 2010). Gejala klinis pada ikan gurame yang terinfeksi bakteri tersebut terlihat berenang lemah, adanya luka pada kulit dan mata menonjol (exopthalmia) (Purwaningsih et al., 2009). Selain gejala tersebut menurut Rukmono (2003), ikan gurame yang terserang mycobacteriosis memperlihatkan gejala klinis seperti lesi nekrotik pada ekor dan perdarahan di bagian bawah sirip. Secara patologi anatomi pada organ yang terinfeksi terlihat adanya tuberkel dan secara histopatologi terlihat adanya radang granuloma pada berbagai organ internal seperti: hati, ginjal, limpa.

Penanganan infeksi bakterial sering dilakukan dengan menggunakan antibiotika. Namun demikian, efektivitas pengobatan dengan antibiotika untuk bakteri intraseluler seringkali memberikan keberhasilan yang rendah. Hal ini disebabkan oleh ketidakmampuan obat tersebut untuk mencapai patogen dan ketidakefektifan obat bekerja dalam lingkungan intraseluler. Penggunaan antibiotika yang tidak tepat sasaran dapat mengakibatkan terjadinya resistensi dan residu antibiotika. Sehubungan dengan tidak efektifnya penggunaan antibiotika untuk pengobatan mycobacteriosis, pencegahan penyakit tersebut dengan menggunakan vaksin menjadi salah satu alternatif yang dapat dikembangkan. Penggunaan vaksin pada ikan menurut Sommerset et al. (2005), telah menurunkan ketergantungan penggunaan antibiotika pada budidaya ikan.

Vaksin mengandung antigen yang mampu merangsang terbentuknya kekebalan tubuh. Kekebalan tubuh yang terbentuk diharapkan mampu melindungi tubuh dari serangan penyakit dengan jenis patogen yang sama. Vaksinasi dengan vaksin M. bovis bacillus Calmette-Guerin (BCG) untuk pencegahan terhadap tuberculosis pada manusia dan sapi cukup efektif dila- kukan (Thom et al., 2012). Upaya pencegahan mycobacteriosis pada ikan telah diupayakan oleh Pasnik \& Smith (2006) pada striped bass (Morone saxatilis) menggunakan vaksin Ag85A, dengan nilai RPS antara 88\%$91 \%$ setelah diuji tantang dengan $M$. marinum. Upaya pengembangan vaksin untuk mencegah mycobacteriosis pada ikan gurame telah diteliti oleh Bangkit (2011) dengan mengunakan vaksin sediaan broth dan diperoleh sintasan relatif pada ikan sebesar $80 \%$ setelah uji tantang. Purwaningsih (2013) juga telah melakukan uji coba vaksin sediaan sel utuh dengan nilai relatif percent survival (RPS) sebesar 78\%.

Bakteri memiliki kemampuan untuk mengeluarkan produk metabolisme pada lingkungan hidupnya yang dikenal dengan nama produk ekstraseluler (extracellular product/ECP). Produk ekstraseluler mudah dikenali oleh inang sehingga berpotensi untuk dikembangkan sebagai vaksin (Zou et al., 2011). Mycobacterium spp. memiliki antigen potensial yaitu secreted protein dan heat shock protein (Hsp) (Mikkelsen et al., 2011). Studi tentang proteksi vaksin ECP dari secreted protein $M$. fortuitum pada ikan gurame telah dilakukan oleh Taukhid et al. (2013), dengan nilai RPS sebesar 26,67\% dan 40\%. Potensi ECP yang berasal dari Hsp M. fortuitum pada ikan gurame sampai saat ini belum diketahui, sehingga perlu dilakukan kajian tentang potensi ECP dari Hsp M. fortuitum terutama tentang toksisitas dan imunogenisitas ECP tersebut sebagai salah satu kandidat vaksin untuk pencegahan mycobacteriosis.

\section{BAHAN DAN METODE}

\section{Ikan Uji}

Ikan uji berupa ikan gurame. Ikan gurame yang digunakan untuk uji toksisitas memiliki bobot 15,06 $\pm 0,77 \mathrm{~g}$; sedangkan untuk uji imunogenisitas menggunakan ikan dengan bobot 25-30 g. Ikan yang digunakan telah melewati masa aklimatisasi selama 20 hari.

\section{Preparasi ECP}

Isolat bakteri yang digunakan untuk produksi ECP adalah M. fortuitum isolat 31 koleksi BPPBAT Bogor. Bakteri diinokulasi pada media sauthon cair dan diinkubasi selama 12 hari pada $28^{\circ} \mathrm{C}$ dan dilanjutkan dua hari pada suhu $37^{\circ} \mathrm{C}$. Isolasi ECP mengacu pada metode Chen et al. (1997) dengan modifikasi dan hasil kultur bakteri kemudian diinaktivasi pada suhu $75^{\circ} \mathrm{C}$ selama 15 menit. Hasil inaktivasi disentrifugasi pada kecepatan $7.000 \mathrm{~g}$ selama satu jam pada suhu $4^{\circ} \mathrm{C}$. Supernatan yang berisi ECP crude kemudian disaring dengan menggunakan kertas Whatman No. 1 dengan pore size $11 \mu \mathrm{m}$ dilanjutkan dengan syringe filter steril 0,22 $\mu \mathrm{m}$. ECP kemudian dikonsentrasikan menggunakan poliethilen glikol (PEG) 6.000, hasil 
konsentrasi disimpan pada suhu $-20^{\circ} \mathrm{C}$ hingga digunakan untuk analisis lebih lanjut. Penentuan kadar protein dilakukan menggunakan metode Bradford.

\section{Pengujian Toksisitas ECP}

Uji toksisitas ECP menggunakan perlakuan dengan konsentrasi ECP yang berbeda, yaitu: 7,15 $\mu \mathrm{g} /$ ikan; 14,3 $\mu \mathrm{g} / \mathrm{ikan} ; 28,6 \mu \mathrm{g} / \mathrm{ikan}$; dan 57,2 $\mu \mathrm{g} / \mathrm{ikan}$; serta kontrol dengan PBS $(0,1 \mathrm{~mL})$ dengan tiga kali ulangan. Sebanyak 30 ekor ikan uji masing-masing diinjeksi secara intraperitonial (i.p) sesuai dengan perlakuan. Ikan dipelihara selama dua minggu pada bak berukuran $60 \mathrm{~cm}$ x $70 \mathrm{~cm}$ x $40 \mathrm{~cm}$. Pakan komersial diberikan dua kali sehari dengan kandungan protein 31\%-33\% dan kadar lemak 3\%-5\%.

Pengambilan sampel untuk uji performa darah dilakukan pada hari ke-1, 4, 7, 10, dan 13 pasca injeksi ECP yang meliputi hematokrit (Docan et al., 2010) dan hemoglobin dengan metode Sahli. Pengambilan sampel untuk uji histopatologi (HP) dilakukan pada hari ke-7 dan ke-13 pasca injeksi ECP. Pewarnaan preparat uji HP menggunakan haematoxillin eosin (HE).

\section{Pengujian Imunogenisitas ECP}

Uji imunogenisitas dilakukan menggunakan tiga perlakuan yaitu: ECP dengan adjuvan (Freund incomplete adjuvant/FIA), ECP tanpa adjuvan dan kontrol (sauthon broth). Masing-masing perlakuan menggunakan 45 ekor ikan uji dan ikan diinjeksi sebanyak $0,15 \mathrm{~mL}$ secara i.p dan dipelihara selama lima minggu pada bak berukuran $60 \mathrm{~cm}$ x $70 \mathrm{~cm}$ x $40 \mathrm{~cm}$. Setiap perlakuan dengan tiga kali ulangan. Pengambilan sampel darah untuk melihat respons imun spesifik dan non-spesifik dilakukan pada minggu ke-1, 2, 3,4 , dan 5 pasca injeksi. Pakan yang diberikan adalah pakan komersial sebanyak dua kali sehari dengan kandungan protein 31\%-33\% dan kadar lemak 3\%-5\%. Parameter uji yang diamati adalah respiratory burst (uji NBT), aktivitas lisosim, persentase fagositosis, dan titer antibodi.

\section{Uji Respiratory Burst (NBT)}

Sebanyak $50 \mu \mathrm{L}$ darah dengan antikoagulan diletakkan pada sumur mikroplate berbentuk "U", diinkubasi selama satu jam pada suhu $37^{\circ} \mathrm{C}$, kemudian dibilas dengan $100 \mu \mathrm{L}$ PBS sebanyak tiga kali dan ditambahkan $50 \mu \mathrm{L} 0,2 \%$ nitroblue tetrazolium (NBT) dan diinkubasi selama satu jam pada suhu $25^{\circ} \mathrm{C}$. Setelah itu, larutan difixasi dengan $50 \mu \mathrm{L}$ metanol 100\% selama 2-3 menit, kemudian dibilas tiga kali dengan $50 \mu \mathrm{L}$ metanol $30 \%$ sebanyak tiga kali. Kemudian dikering-anginkan, selanjutnya ditambahkan $60 \mu \mathrm{L}$ kalium hydroxide, serta $70 \mu \mathrm{L}$ dimethylsulfoxide (DMSO). Selanjutnya dibaca dengan menggunakan ELISA reader pada panjang gelombang $540 \mathrm{~nm}$.

\section{Aktivitas Lisosim}

Aktivitas lisosim diuji dengan menggunakan Micrococcus lysodekticus $\left(0,2 \mathrm{mg} / \mathrm{mL}\right.$ dalam $\left.0,05 \mathrm{M} \mathrm{NaH}_{2} \mathrm{PO}_{4}\right)$. Serum sebanyak $10 \mu \mathrm{L}$ dimasukkan pada sumur mikroplate berbentuk "U", kemudian ditambahkan 190 $\mu \mathrm{L}$ suspensi bakteri. Pembacaan absorbansi dilakukan pada panjang gelombang $540 \mathrm{~nm}$ setelah 30 detik dan 4,5 menit inkubasi menggunakan ELISA reader.

\section{Persentase Fagositosis}

Persentase fagositosis dievaluasi menggunakan metode Anderson \& Siwicki (1995). Sebanyak $50 \mu \mathrm{L}$ suspensi Staphylococcus aureus kepadatan $10^{7} \mathrm{cfu} / \mathrm{mL}$ dimasukkan ke dalam tabung mikrotub, ditambahkan $50 \mu \mathrm{L}$ darah, kemudian diinkubasi selama 20 menit. Setelah itu, dibuat preparat ulas, selanjutnya difixasi dengan metanol selama lima menit dan diwarnai dengan Giemsa selama 15 menit. Preparat diamati di bawah mikroskop. Persen fagositosis (PP) dihitung menggunakan rumus:

$$
\mathrm{PP}=(\mathrm{N} 1 / 100) \times 100
$$

$\mathrm{N} 1$ = Total proses fagositosis yang dilakukan oleh sel fagosit dari 100 sel fagosit yang terhitung

\section{Titer Antibodi}

Pengujian titer antibodi dilakukan dengan metode aglutinasi, menggunakan mikroplate berbentuk "U". Sebanyak $25 \mu \mathrm{L}$ PBS dimasukkan ke dalam sumur No. 1 sampai sumur No. 12, kemudian ditambahkan $25 \mu \mathrm{L}$ serum pada sumur No. 1, kemudian homogenkan dan dilakukan pengenceran serial sampai sumur No. 11. Sumur No. 12 digunakan sebagai kontrol negatif. Sebanyak $25 \mu \mathrm{L}$ bakteri $M$. fortuitum dimasukkan pada semua sumur dan dihomogenkan dengan cara digoyang membentuk angka delapan. Plate diinkubasi dalam inkubator pada suhu $37^{\circ} \mathrm{C}$ selama dua jam dan kemudian dilanjutkan pada refrigerator $4^{\circ} \mathrm{C}$ semalaman, selanjutnya titer aglutinasi dihitung dan nilai titer dimasukkan dalam hitungan $\log 2$.

\section{Analisis Data}

Nilai hematokrit, hemoglobin, respiratory burst, aktivitas lisosim, persentase fagositik, dan titer antibodi dianalisis dengan ANOVA pada selang kepercayaan 95\% menggunakan program SPSS 16. Hasil uji histopatologi dianalisis secara deskriptif.

\section{HASIL DAN BAHASAN}

\section{Pengujian Toksisitas ECP}

\section{Performa darah}

Selama pengamatan tidak terjadi adanya kematian ikan uji pada empat konsentrasi ECP yang digu- 
nakan (7,15 $\mu \mathrm{g} / \mathrm{ikan} ; 14,3 \mu \mathrm{g} / \mathrm{ikan} ; 28,6 \mu \mathrm{g} / \mathrm{ikan}$; dan $57,2 \mu \mathrm{g} / \mathrm{ikan})$. Pengamatan terhadap performa darah dapat digunakan untuk melihat perubahan fisiologi yang disebabkan oleh stres dan status kesehatan ikan. Dilihat dari kadar hematokrit, pada hari ke-13 terjadi penurunan kadar hematokrit pada ikan yang diinjeksi ECP dengan konsentrasi protein $28,6 \mu \mathrm{g} /$ ikan $(16,52 \pm 2,25 \%)$ dan 57,2 $\mu \mathrm{g} / \mathrm{ikan}(18,62 \pm 1,24 \%)$ yang berbeda nyata $(\mathrm{P}<0,05)$ jika dibandingkan dengan kontrol $(21,93 \pm 0,99 \%)$ (Gambar 1 kiri).

Nilai terendah kadar hemoglobin pada hari pertama setelah injeksi ECP sebesar $6 \pm 0,2 \mathrm{~g} / \mathrm{dL}$; penurunan kadar hemoglobin terjadi pada empat hari setelah injeksi ECP dengan nilai hemoglobin terendah yaitu $5,33 \pm 0,5 \mathrm{~g} / \mathrm{dL}$; setelah itu, kadar hemoglobin naik kembali dan tidak ada perbedaan yang signifikan dengan kontrol (Gambar 1 kanan). Menurut Chen et al. (1997), ЕСР M. fortuitum tidak memiliki kandungan enzim hemolisin yang dapat melisiskan sel darah merah dan mengakibatkan rendahnya nilai hemoglobin darah akibat terjadi anemia. Pengamatan terhadap kadar hematokrit dan hemoglobin memperlihatkan bahwa ECP M. fortuitum memengaruhi kondisi fisiologis ikan. Hasil pemeriksaan hematokrit dan hemoglobin dapat dijadikan indikator untuk menentukan kesehatan ikan.

\section{Performa histopatologi}

Pengamatan histopatologi dilakukan pada organ hati dan ginjal untuk melihat ada tidaknya kerusakan pada organ tersebut akibat injeksi ECP M. fortuitum. Hasil pengamatan terlihat adanya degenerasi lemak dan inti sel yang tidak seragam pada organ hati (Gambar 2 dan Tabel 1) dan ginjal (Gambar 3 dan Tabel 2), tetapi tidak menunjukkan adanya nekrosa. Degene- rasi lemak terjadi baik pada ikan kontrol maupun perlakuan. Degenerasi lemak tidak selalu mengindikasikan adanya proses patologi. Dunlop \& Malbert (2004) menyatakan bahwa degenerasi lemak dapat terlihat pada kondisi fisiologi seperti adaptasi atau disfungsi patologi.

Degenerasi lemak merupakan akumulasi lemak pada sitoplasma sel, sel tidak mampu melakukan metabolisme lemak dengan baik sehingga terjadi akumulasi lemak dalam sel. Degenerasi lemak terjadi pada sel hidup dan bersifat reversible, serta tidak membahayakan fungsi organ (Jones et al., 2006). Menurut Haschex \& Rousseaux (1998), degenerasi lemak yang bersifat sedang (moderate) tidak mengganggu fungsi hati. Perubahan patologi yang terdapat pada organ ginjal merupakan lanjutan dari kondisi yang terlihat di organ hati, karena darah akan dinetralisir terlebih dahulu di organ hati dan selanjutnya difiltrasi di organ ginjal.

Berbeda dengan mamalia, sel hati ikan lebih bervakuola karena berisi lemak dan glikogen (Ferguson, 1989 dalam Wolf \& Wolfe, 2005), tetapi proporsi lemak dan glikogen yang disimpan dalam sel hati pada setiap jenis ikan berbeda-beda. Degenerasi lemak pada ikan dapat disebabkan karena ikan memiliki kemampuan menyimpan lemak dalam jumlah besar di dalam organ hati atau juga karena faktor nutrisi (Wolf $\&$ Wolfe, 2005).

Dilihat dari inti sel organ hati, terlihat mulai adanya ketidak seragaman sel inti pada ikan yang diinjeksi ECP dengan konsentrasi 14,3 $\mu \mathrm{g} / \mathrm{ikan}$. Sementara di organ ginjal, inti sel tubulus terlihat tidak seragam pada ikan yang diinjeksi ECP sebesar 57,20 $\mu \mathrm{g} / \mathrm{ikan}$. Ketidakseragaman inti sel merupakan respons awal
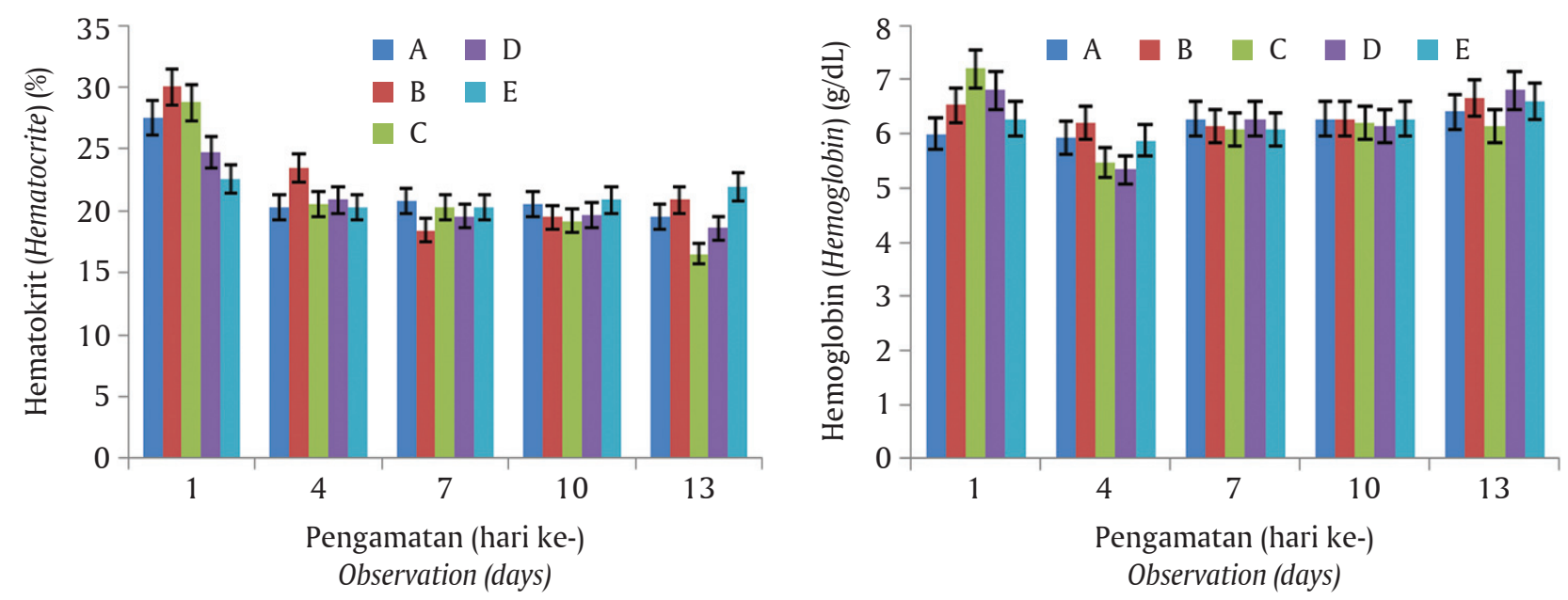

Gambar 1. Kadar hematokrit (kiri) dan hemoglobin (kanan) ikan gurame yang diinjeksi ECP dengan konsentrasi: (A) 7,15 $\mu \mathrm{g} / \mathrm{ikan}$; (B) 14,3 $\mu \mathrm{g} / \mathrm{ikan}$; (C) 28,6 $\mu \mathrm{g} / \mathrm{ikan}$; (D) 57,2 $\mu \mathrm{g} / \mathrm{ikan}$; dan (E) kontrol

Figure 1. Hematocrite (left) and hemoglobin level (right) of giant gouramy injected with ECP at a concentration of (A) $7.15 \mu \mathrm{g} /$ fish; (B) $14.3 \mu \mathrm{g} /$ fish; (C) $28.6 \mu \mathrm{g} /$ fish; (D) $57.2 \mu \mathrm{g} /$ fish; and (E) control 


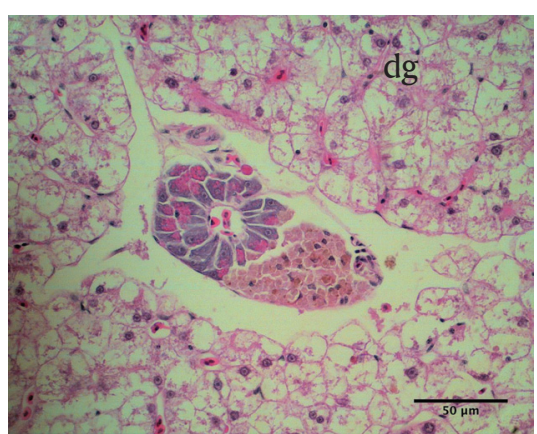

$7,15 \mu \mathrm{g} / \mathrm{ikan}(7.5 \mu \mathrm{g} / \mathrm{fish})$

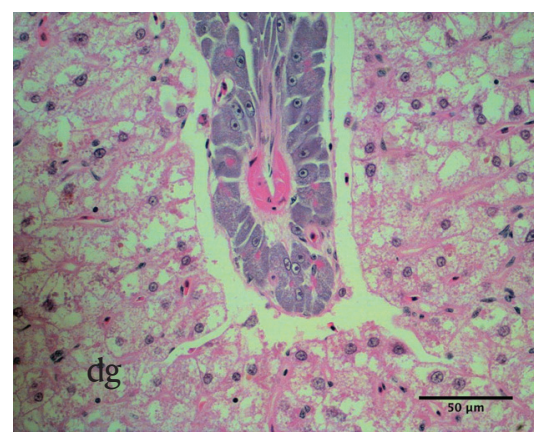

$14,3 \mu \mathrm{g} / \mathrm{ikan}(14.3 \mu \mathrm{g} / \mathrm{fish})$

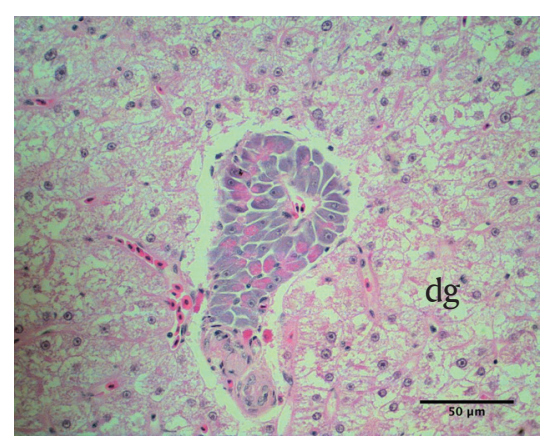

$28,6 \mu \mathrm{g} / \mathrm{ikan}(28.6 \mu \mathrm{g} / \mathrm{fish})$

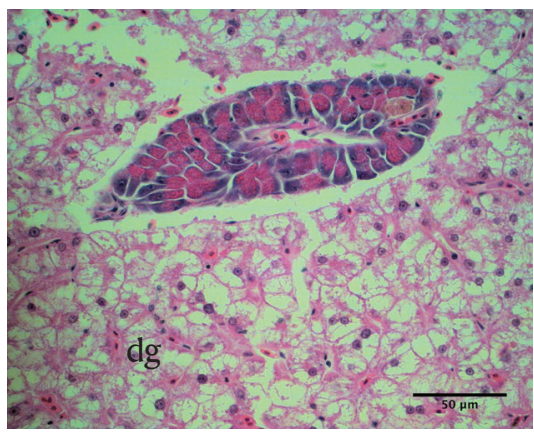

$57,2 \mu \mathrm{g} / \mathrm{ikan}(57.2 \mu \mathrm{g} / \mathrm{fish})$

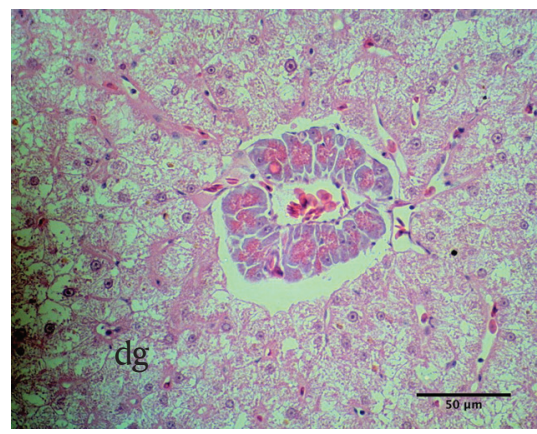

Kontrol (Control)

Gambar 2. Histopatologi organ hati ikan gurame yang diinjeksi ECP M. fortuitum menunjukkan adanya degenerasi lemak (dg)

Figure 2. Histopathological of liver giant gouramy injected with ECP M. fortuitum showed that fatty degeneration (dg)

Tabel 1. Hasil pengamatan histopatologi organ hati ikan gurame yang diinjeksi ECP M. fortuitum

Table 1. Histopatological result of liver giant gouramy injected with ECP M. fortuitum

\begin{tabular}{cccc}
\hline $\begin{array}{c}\text { Konsentrasi ECP }\left(\mu \mathrm{g} \mathrm{ikan}^{-1}\right) \\
\text { Concentration of ECP }\left(\mu \mathrm{g} \text { fish }^{-1}\right)\end{array}$ & $\begin{array}{c}\text { Degenerasi lemak } \\
\text { Fatty degeneration }\end{array}$ & $\begin{array}{c}\text { Inti sel tidak seragam } \\
\text { Nucleus ununiform }\end{array}$ & $\begin{array}{c}\text { Nekrosa } \\
\text { Necrosis }\end{array}$ \\
\hline 7.15 & + & - & - \\
14.3 & + & + & - \\
28.6 & + & + & - \\
57.2 & + & + & - \\
0 & + & - & - \\
\hline
\end{tabular}

Keterangan (Note):

$+=$ Ditemukan perubahan (Changed happen); - = Tidak ditemukan perubahan (No changed happen)

dari kerusakan organ, hal ini menunjukkan bahwa ECP berpengaruh terhadap keseragaman inti sel organ hati maupun inti sel tubulus organ ginjal.

Dilihat dari parameter darah dan performa histopatologi menunjukkan bahwa ECP M. fortuitum tidak bersifat toksik pada ikan gurame. Produk ekstraseluler yang disekresikan oleh bakteri patogen termasuk dalam golongan eksotoksin, sifat toksik dari eksotoksin dapat hilang jika dipanaskan atau diberi perlakuan kimia seperti fenol atau formaldehid. Eksotoksin yang telah kehilangan toksisitasnya dinamakan dengan toksoid, dan toksoid memiliki kemam- puan untuk menginduksi antibodi antitoksoid (Kuby, 2007). Konsentrasi ECP yang aman digunakan dan tidak menyebabkan inti sel hati menjadi tidak seragam berada pada konsentrasi di bawah $14,30 \mu \mathrm{g} / \mathrm{ikan}$ atau $0,95 \mu \mathrm{g} / \mathrm{g}$ bobot badan ikan.

\section{Pengujian Imunogenisitas ECP}

\section{Respons Imun Non-Spesifik (NBT, Persentase Fagositosis, dan Aktivitas Lisosim)}

Respons imun non-spesifik dapat dilihat dari nilai NBT, persentase fagositosis, dan aktivitas lisosim. Ni- 


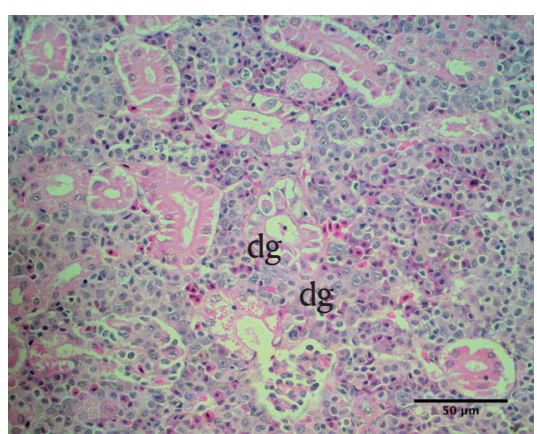

$7,15 \mu \mathrm{g} / \mathrm{ikan}(7.5 \mu \mathrm{g} / \mathrm{fish})$

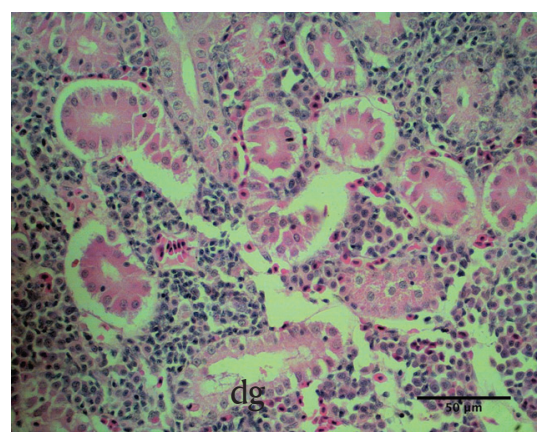

$14,3 \mu \mathrm{g} / \mathrm{ikan}(14.3 \mu \mathrm{g} / \mathrm{fish})$

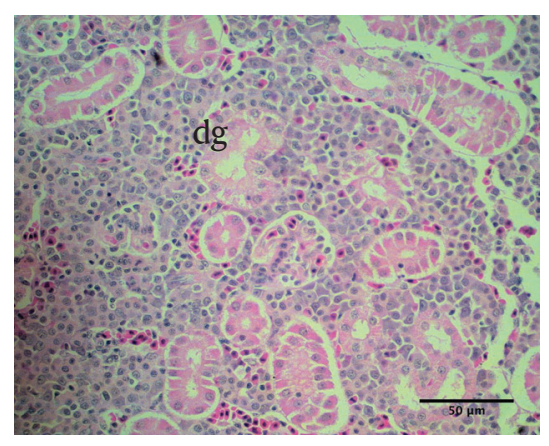

$28,6 \mu \mathrm{g} / \mathrm{ikan}(28.6 \mu \mathrm{g} / \mathrm{fish})$

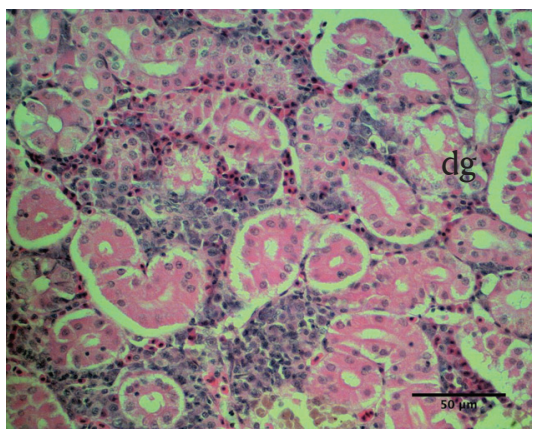

$57,2 \mu \mathrm{g} / \mathrm{ikan}(57.2 \mu \mathrm{g} / \mathrm{fish})$

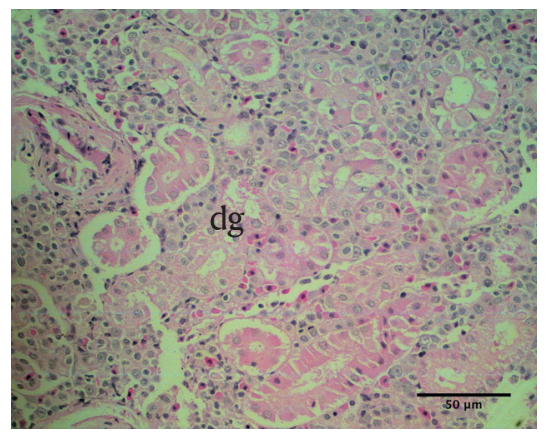

Kontrol (Control)

Gambar 3. Histopatologi organ ginjal ikan gurame yang diinjeksi ECP M. fortuitum menunjukkan adanya degenerasi lemak $(\mathrm{dg})$

Figure 3. Histopathological of kidney giant gouramy injected with ECP M. fortuitum showed that fatty degeneration (dg)

Tabel 2. Hasil pengamatan histopatologi organ ginjal ikan gurame yang diinjeksi ECP M. fortuitum Table 2. Histopathological result of kidney giant gouramy injected with ECP M. fortuitum

\begin{tabular}{cccc}
\hline Konsentrasi ECP $\left(\mu \mathrm{g} \mathrm{ikan}^{-1}\right)$ & $\begin{array}{c}\text { Degenerasi lemak } \\
\text { Fatty degeneration }\end{array}$ & $\begin{array}{c}\text { Inti sel tidak seragam } \\
\text { Nucleus ununiform }\end{array}$ & $\begin{array}{c}\text { Nekrosa } \\
\text { Necrosis }\end{array}$ \\
\hline 7.15 & + & - & - \\
14.3 & + & - & - \\
28.6 & + & - & - \\
57.2 & + & + & - \\
0 & + & - & - \\
\hline
\end{tabular}

Keterangan (Note):

$+=$ Ditemukan perubahan (Changed happen); - = Tidak ditemukan perubahan (No changed happen)

lai NBT pada minggu kedua mengalami peningkatan jika dibandingkan dengan pada minggu pertama sebesar 5,2\% untuk ikan yang diinjeksi ECP dengan adjuvan (FIA); 5,3\% untuk ikan yang diinjeksi dengan ECP dan 3,6\% untuk ikan kontrol yang diinjeksi dengan sauthon broth. Nilai NBT tertinggi terjadi pada minggu ke-5 yaitu sebesar 0,284 (Gambar 4); secara statistik terdapat perbedaan yang nyata $(\mathrm{P}<0,05)$ antara ikan perlakuan dengan kontrol.

Pada minggu pertama pasca injeksi terlihat nilai NBT yang rendah hal ini kemungkinan karena neutrofil bermigrasi dari pembuluh darah ke daerah luka.
Rendahnya nilai NBT pada minggu pertama juga ditemukan oleh Choi \& Oh (2000) yang menginjeksikan ECP Mycobacterium spp. pada gelembung renang ikan nila. Neutrofil memiliki peranan besar dalam respons imun non-spesifik, menurut Tizard (2004), granul primer pada neutrofil berfungsi untuk menghasilkan enzim myeloperoksidase yang berperan dalam proses respiratory burst. Pada proses respiratory burst dihasilkan radical oxygen species (ROS) seperti superoxide $\left(\mathrm{O}_{2}^{-}\right)$, hidrogen peroksida $\left(\mathrm{H}_{2} \mathrm{O}_{2}\right)$, dan hipoklorit $(\mathrm{OCl})$. ROS berperan untuk melawan patogen yang masuk (Kuby, 2007). Produksi ROS dapat dilihat dengan meng- 
gunakan pewarna NBT, semakin tinggi nilai NBT menunjukkan produksi ROS selama proses respiratory burst semakin besar. Menurut Anderson (2004), uji NBT dapat digunakan untuk melihat respons imun non-spesifik setelah aplikasi imunostimulan dan vaksin. Peningkatan nilai NBT setelah aplikasi vaksin juga ditemukan oleh Purwaningsih (2013) melalui aplikasi vaksin sel utuh $M$. fortuitum pada ikan gurame.

Persentase fagositosis pada ikan yang diinjeksi ECP baik dengan adjuvan maupun ECP tanpa adjuvan mencapai puncaknya pada minggu ke-2 (Gambar 5) dan terdapat perbedaan yang nyata $(\mathrm{P}<0,05)$ antara ikan perlakuan dengan kontrol. Sel fagosit yang berperan dalam proses fagositosis adalah neutrofil dan makrofag. Makrofag diaktifkan oleh berbagai stimulus (Kuby, 2007), peningkatan fagositosis pada ikan baik yang diinjeksi ECP dengan FIA maupun ECP saja menunjukkan bahwa ECP mampu merangsang teraktivasinya sel fagosit yang berperan dalam melawan patogen yang masuk. Peningkatan persentase fagositosis juga ditemukan pada ikan nila yang diinjeksi oleh bivalen ECP Streptococcus agalactiae (Sugiani, 2012) dan ikan gurame yang diinjeksi dengan vaksin sel utuh M. fortuitum (Purwaningsih, 2013). Fagositosis merupakan suatu mekanisme pertahanan tubuh yang dilakukan oleh sel fagosit dengan cara mencerna benda asing dan kemudian menghancurkannya. Menurut Wibawan \& Soejoedono (2013), proses fagositosis berlangsung dalam lima fase yaitu pergerakan, perlekatan, penelanan (ingestion), degranulasi, dan pembunuhan (killing).

Aktivitas lisosim meningkat dan mencapai puncaknya pada minggu ke-3 dan terdapat perbedaan yang nyata $(\mathrm{P}<0,05)$ antara perlakuan dengan kontrol

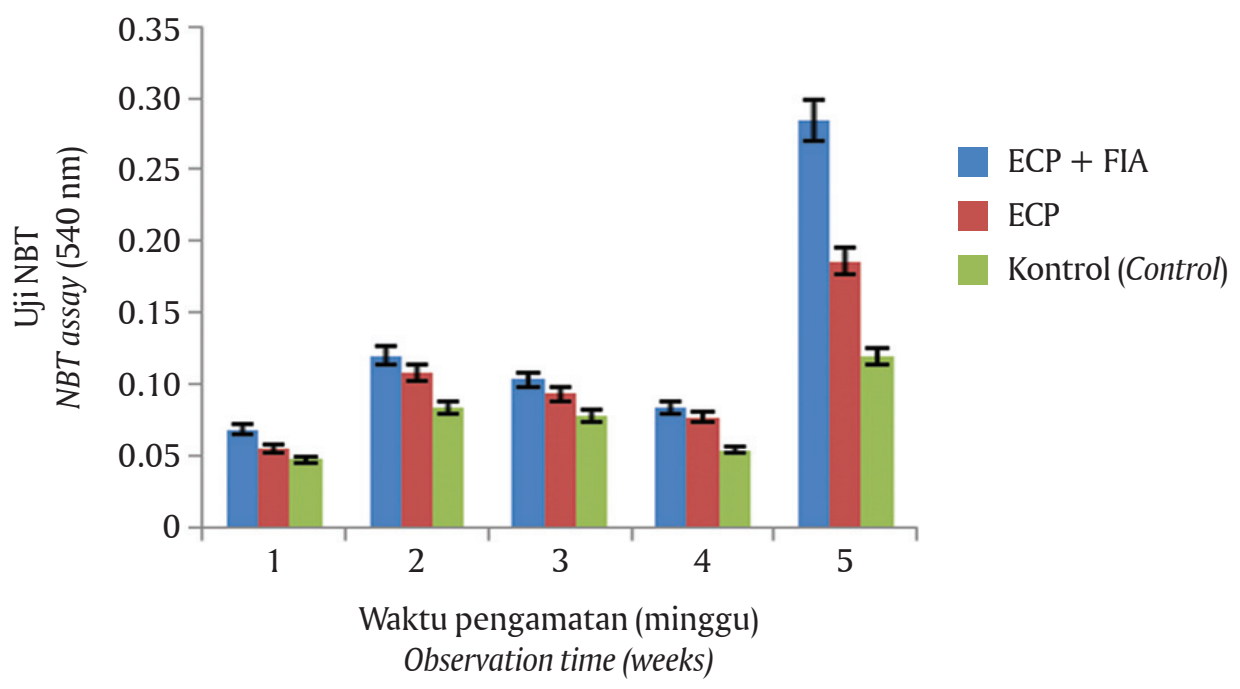

Gambar 4. Hasil uji NBT ikan gurame yang diinjeksi ECP M. fortuitum

Figure 4. NBT assay of giant gouramy injected with ECP M. fortuitum

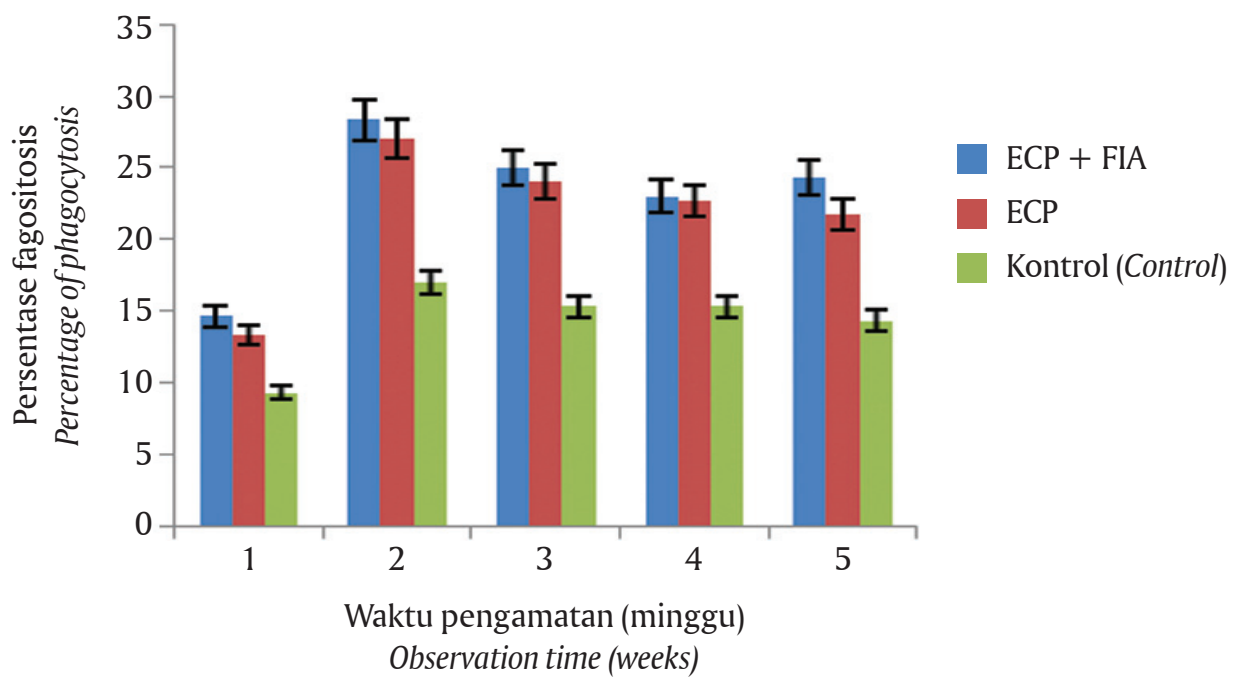

Gambar 5. Persentase fagositosis ikan gurame yang diinjeksi ECP M. fortuitum

Figure 5. Percentage phagocytosis of giant gouramy injected with ECP M. fortuitum 
(Gambar 6). Peningkatan aktivitas lisosim juga diperoleh pada ikan nila yang diinjeksi ECP Pseudomonas fluorescens (Attia et al., 2012). Hal yang sama terjadi pada ikan nila yang injeksi bivalen vaksin ECP Streptococcus agalactiae (Sugiani, 2012).

Lisosim merupakan komponen yang penting dalam sistem pertahanan tubuh terhadap patogen yang masuk. Lisosim pada ikan dapat dideteksi dari serum, mukus, plasma, dan organ ikan seperti insang dan hati, lisosim pada ikan merupakan indikator nonspesifik respons terhadap invasi antigen yang masuk (Saurabh \& Sahoo, 2008). Lisosim merupakan enzim yang dapat menghidrolisis ikatan $\beta(1-\rightarrow 4)$ antara Nacetylmuramic acid dan $\mathrm{N}$-acetylglucosamine pada dinding sel (peptidoglikan) bakteri baik bakteri Gram positif maupun Gram negatif. Lisosim juga mendorong aktivitas fagositosis yaitu sebagai opsonin atau secara langsung mengaktifkan neutrofil dan makrofag.

Dilihat dari hasil uji NBT, persentase fagositosis dan aktivitas lisosim terlihat bahwa ECP M. fortuitum mampu meningkatkan respons imun non-spesifik pada ikan gurame. Menurut Saurabh \& Sahoo (2008), respons imun non-spesifik merupakan pertahanan lapis pertama yang sangat penting pada ikan jika dibandingkan dengan mamalia untuk melawan patogen yang masuk.

\section{Respons Imun Spesifik (Titer Antibodi)}

Induksi antigen yang memiliki sifat imunogenik akan direspons oleh tubuh dengan membentuk antibodi spesifik. Interaksi antara antigen antibodi dapat berupa presipitasi atau aglutinasi. Hasil uji aglutinasi menunjukkan bahwa ECP M. fortuitum mampu menginduksi terbentuknya antibodi yang spesifik (Gambar 7). Secara statistik titer antibodi pada perlakuan dan kontrol berbeda nyata $(\mathrm{P}<0,05)$; begitu juga antar perlakuan ECP dengan FIA pada minggu ke-4 dan ke-5 terlihat berbeda nyata jika dibandingkan dengan ikan yang diinjeksi ECP saja.

Titer antibodi pada ikan yang diinjeksi ECP saja mencapai puncaknya pada minggu ke-3, sedangkan pada ikan yang diinjeksi ECP dengan FIA pada minggu ke-4. Pemberian adjuvan terlihat mampu meningkatkan dan menstabilkan titer antibodi. Freund incomplete adjuvant merupakan water in oil (W/O) emulsion, dengan mekanisme melepaskan antigen secara perlahan-lahan, imunitas yang diinduksi oleh adjuvan tipe W/O bersifat kuat dan lama (Aucouturier et al., 2001). Menurut Kuby (2007), adjuvan merupakan substansi yang jika dicampurkan dengan antigen kemudian diinjeksikan bersama akan bekerja memperbesar imunogenisitas antigen. Peningkatan titer antibodi juga terlihat pada ikan zebrafish yang diinjeksi ECP M. marinum (Cui et al., 2010) dan ikan gurame yang diinjeksi dengan vaksin sel utuh M. fortuitum (Purwaningsih, 2013).

Antibodi merupakan respons imun humoral dan berfungsi untuk menetralkan antigen. Fungsi vital antibodi dalam proses netralisasi antigen menurut Wibawan \& Soejoedono (2013), adalah sebagai: (1) inhibin yaitu menghambat adhesi antigen pada permukaan sel target; (2) aglutinin yakni antibodi bereaksi dengan antigen dan menggumpalkannya dalam bentuk aglutinat yang tidak larut; (3) presipitin yakni antibodi bereaksi dengan antigen (terlarut) dan membentuk presipitat yang tidak larut; dan (4) opsonin yaitu antibodi akan melekat pada permukaan antigen dan menyebabkan makrofag lebih agresif melakukan proses fagositosis.

Ikan bertulang belakang memiliki imunoglobulin yang terbatas jika dibandingkan dengan mamalia. Ikan

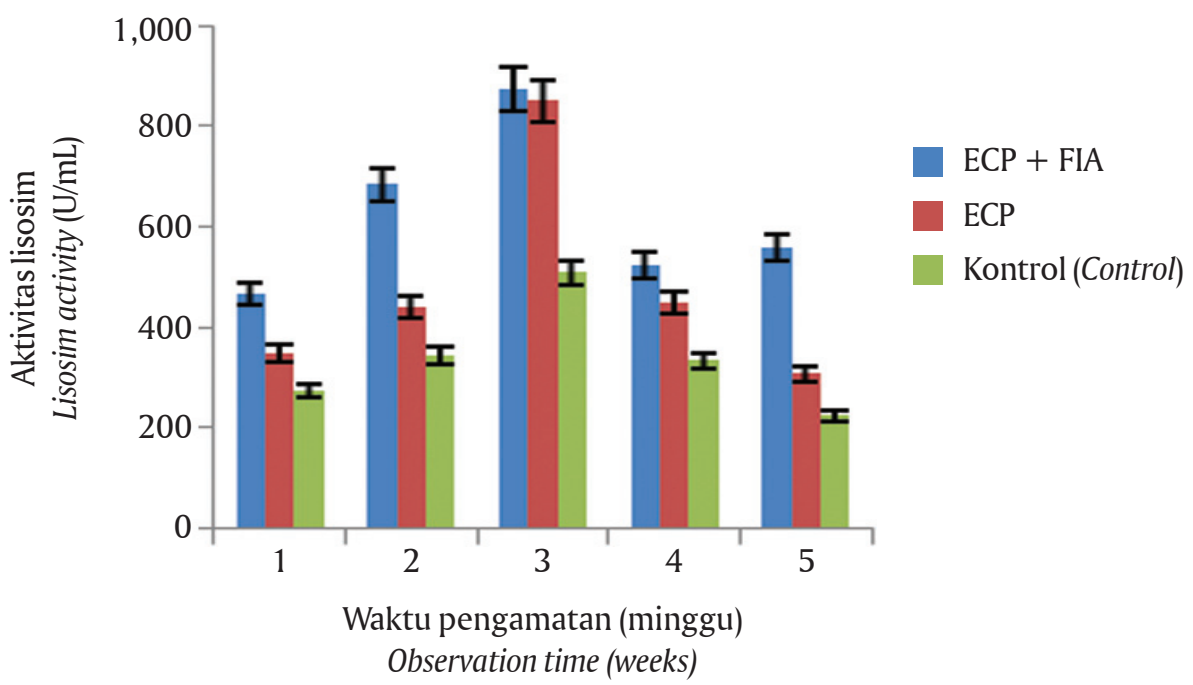

Gambar 6. Aktivitas lisosim ikan gurame yang diinjeksi ECP dari M. fortuitum Figure 6. Lisosim activity of giant gouramy injected with ECP of M. fortuitum 


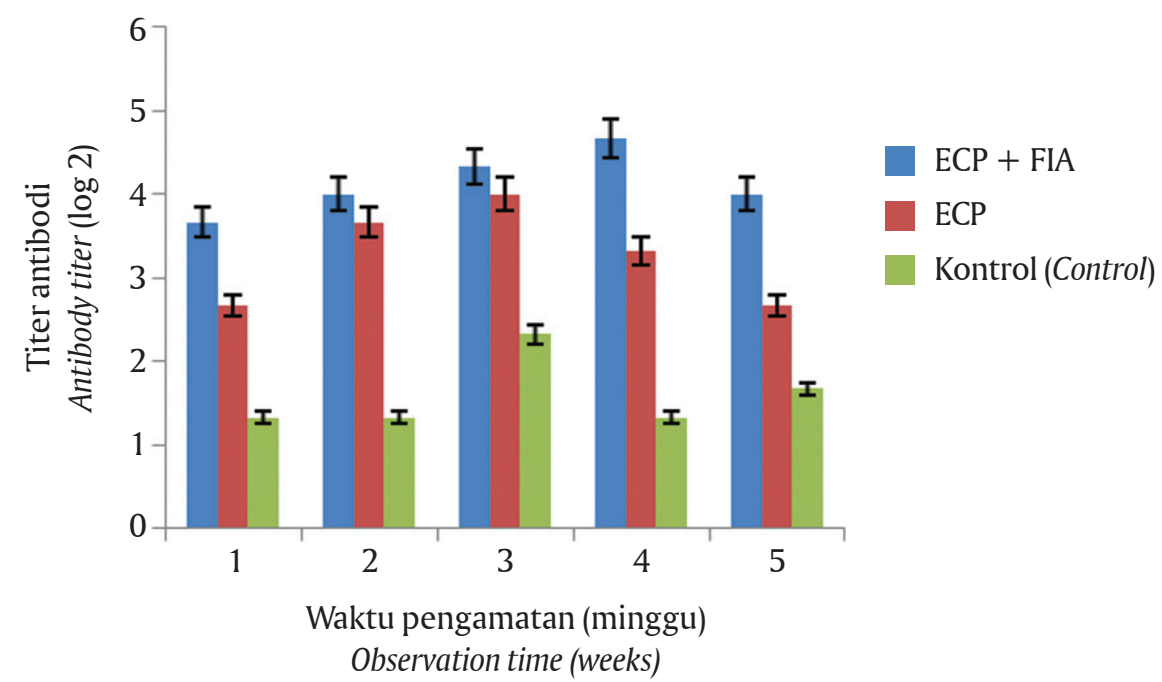

Gambar 7. Titer antibodi ikan gurame yang diinjeksi ECP dari M. fortuitum

Figure 7. Antibody titer of giant gouramy injected with ECP of M. fortuitum

hanya memiliki satu kelas imunoglobulin yaitu IgMlike. Menurut Bengten et al. (2006), IgM-like memiliki struktur tetramer yang terdiri atas delapan rantai berat (heavy chain/H) dan delapan rantai ringan (light chain/L). Terbentuknya antibodi pada ikan pasca vaksinasi menunjukkan bahwa ikan memiliki kemampuan untuk merespons antigen dengan membentuk antibodi yang spesifik terhadap antigen, meskipun menurut Pellitero (2008), titer antibodi yang tinggi pada ikan tidak selalu berkorelasi dengan tingkat proteksi yang ditimbulkan.

Peningkatan titer antibodi menunjukkan bahwa ECP M. fortuitum yang diisolasi dengan kejutan suhu bersifat imunogenik dan mampu menginduksi kekebalan pada ikan. Kejutan suhu membuat sel bakteri mengeluarkan protein stres yang dikenal dengan heat shock protein (Hsp). Hsp mampu menginduksi selular dan humoral respons untuk melawan patogen yang masuk, menurut Tsan \& Gao (2009), Hsp memiliki peranan penting dalam presentasi antigen, aktifasi limfosit, dan makrofag, serta aktifasi sel dendritik.

\section{KESIMPULAN}

Produk ekstraseluler M. fortuitum yang diisolasi dengan cara heat shock pada suhu $37^{\circ} \mathrm{C}$ selama dua hari dan diinaktifasi pada suhu $75^{\circ} \mathrm{C}$ hingga konsentrasi $57,2 \mu \mathrm{g} /$ ikan tidak bersifat toksik pada ikan gurame. Respons imun non-spesifik dan spesifik pada ikan gurame menunjukkan bahwa ECP M. fortuitum bersifat imunogenik sehingga berpotensi untuk dikembangkan sebagai vaksin guna penanggulangan mycobacteriosis.

\section{UCAPAN TERIMA KASIH}

Penulis mengucapkan terima kasih kepada Balai Penelitian dan Pengembangan Budidaya Air Tawar,
Bogor atas fasilitas selama penelitian dan juga kepada peneliti dan teknisi yang telah banyak membantu selama penelitian berlangsung.

\section{DAFTAR ACUAN}

Anderson, D.P., \& Siwicki, A.K. (1995). Basic hematology and serology for fish health programs. Dalam Shariff, M., Arthur, J.R., Subasinghe, R.P., editor. Fish Health Section. Asia Fisheries Society (Eds.), Disease in Asian Aquaculture II. Manila. Philippines, p. 185-202.

Anderson, D.P. (2004). Immunostimulants, vaccines and environmental stressor in aquaculture; NBT assay to show neutrofil activity by these immunomodulators. In Suarez, C. et al. (Eds.), Avances en acuicola VII. Memorias del Simposium International de Nutricion Acuicola. Sonora Mexico, 1619 November, 2004.

Attia, A., Mesalhy, S., Galil, Y.A., \& Fathi, M. (2012). Effect of injection vaccination against Pseudomonas fluorescent on spesific and non-spesific immune response of nile tilapia (Oreochromis niloticus) using different prepared antigens. DOI:10.4172/ scientificreports.552. Scientific Reports, 1(12), 1-7.

Aucouturier, J., Dupuis, L., \& Ganne, V. (2001). Adjuvants designed for veterinary and human vaccines. Vaccine, 19, 2666-2672.

Bangkit, I. (2011). Efektifitas vaksin Mycobacterium fortuitum yang diinaktivasi dengan formalin untuk pencegahan mycobacteriosis pada ikan gurami (Osphronemus gouramy). Skripsi. Jatinangor (ID). Universitas Padjajaran.

Bengten, E., Clem, L.W., Miller, N.W., War, G.W., \& Wilson, M. (2006). Channel catfish imunuglobulins: repertoire and expression. Developmental and Comparative Immunology, 30, 77-92. 
Bracklebank, J., Raverty, S., \& Robinson, J. (2003). Mycobacteriosis in atlantic salmon farmed in British Columbia. Can. Vet. J., 44, 486-489.

Bozzetta, E., varello, K., Giorgi, I., Fioravanti, M.L., Pezzolato, M., Zanoni, T.G., \& Prearo, M. (2010). Mycobacterium marinum infection in hybrid striped bass farm in Italy. Journal of Fish Disease, 33, 781785.

Chang, T.C., Hsieh, C.Y., Chang, C.P., Shen, Y.L., Huang, K.C., Tu, C., Chen, L.C., Wu, Z.B., \& Tsai, S.S. (2006). Pathological and molecular studies on mycobacteriosis of milkfish Chanos chanos in Taiwan. Diseases of Aquatic Organisms, 72, 147-151.

Chen, S.C., Adams, A., \& Richards, R.H. (1997). Extracellular products from Mycobacterium spp. in fish. Journal of Fish Disease, 20, 19-25.

Choi, S.H., \& Oh, C.H. (2000). Stimulatory effect of extracellular product of Mycobacterium spp. and various adjuvants on non spesific immune response of nile tilapia (Oreochromis niloticus). Korean J. Biol. Science, 4, 299-304.

Cui, Z., Shaker, D.S., Watral, V., \& Kent, M.L. (2010). Attenuated Mycobacterium marinum protects zebrafish against mycobacteriosis. Journal of Fish Disease, 33(4), 371-375.

Decostere, A., Hermans, K., \& Haesebrouck, F. (2004). Piscine mycobacteriosis: a literatur review covering the agent and the disease it causes in fish and humans. Veterinary Microbiology, 99, 159-166.

Docan, A., Cristea, V., Grecu, I., \& Dediu, L. (2010). Hematological response of the european catfish, Silurus glanis reared at different densities in flowthrough production system. Archiva Zootechnica, 13(2), 63-70.

Dunlop, R.H., \& Malbert, C.H. (2004). Veterinary pathophysiology. $1^{\text {st }}$ ed. Blackwell Publishing. United State of America (US), 530 pp.

Gauthier, D.T., \& Rhodes, M.W. (2009). Mycobacteriosis in fishes; A review. The Veterinary Journal, 180, 33-47.

Haschek, W., \& Rousseaux, C.G. (1998). Fundamentals of toxicologic pathology. Academic Press. San Diego, 563 pp.

Jones, T.C., Hunt, R.D., \& King, N.W. (2006). Veterinary pathology. $6^{\text {th }}$ ed. Blackwell Publishing. United State of America (US), 1392 pp.

Kuby. (2007). Immunology. $6^{\text {th }}$ ed. W.H. Freeman and Company. New York (US), 574 pp.

Mikkelsen, H., Aagaaard, C., Nielsen, S.S., \& Jungersen, G. (2011). Review of Mycobacterium avium subspecies paratuberculosis antigen candidates with diagnostic potential. Veterinary Microbiology, 152, 1-20.

Pasnik, D.J., \& Smith, S.A. (2006). Immune and his- topathological response of DNA-vaccinated hybrid striped bass Morone saxatilis x M. chrysops after acute Mycobacterium marinum infection. Disease of Aquatic Organisms, 73, 33-41.

Pellitero, P.A. (2008). Fish immunity and parasit infections: from innate immunity to immunoprophylactic prospects. Veterinary Immunology and Immunopathology, 126, 171-198.

Purwaningsih, U., Lusiastuti, A.M., \& Taukhid. (2009). Studi patologi-anatomi penyakit mikobakteriosis pada ikan gurami (Ospronemus gouramy). Prosiding Forum Inovasi Teknologi Akuakultur. hlm. 1139-1142.

Purwaningsih, U. (2013). Vaksin koktail sel utuh untuk pencegahan penyakit mycobacteriosis dan motile aeromonas septicemia pada ikan gurame (Osphronemus gouramy). Tesis. Institut Pertanian Bogor. Bogor (ID).

Rukmono, D. (2010). Deteksi cepat dan akurat penyakit mycobacteriosis pada ikan gurame (Osphronemus gouramy) melalui metode PCR (polymerase chain reaction). Disertasi. Universitas Gadjah Mada. Yogyakarta (ID).

Rukmono, D. (2003). Mycobacterium fortuitum pada ikan gurame (Osphronemus gouramy): diagnosa patologis dan mikrobiologis. Tesis. Universitas Gadjah Mada. Yogyakarta (ID).

Saurabh, S., \& Sahoo, P.K. (2008). Lysozyme: an important defence molecule of fish innate immune system. Aquaculture Research, 39, 223-239.

Sommerset, I., Krossoy, B., Biering, E., \& Frost, P. (2005). Vaccines for fish in aquaculture. Expert Rev. Vaccines, 4, 89-101.

Sugiani, D. (2012). Vaksin bivalent untuk pencegahan penyakit motile aeromonas septicemia dan streptococcosis pada ikan nila (Oreochromis niloticus). Disertasi. Institut Pertanian Bogor. Bogor (ID).

Taukhid, Lusiastuti, A.M., Purwaningsih, U., Sugiani, D., \& Sumiati, T. (2013). Vaksin Mycobacterium fortuitum (MycofortyVac) untuk pencegahan penyakit mycobacteriosis pada ikan gurame (Osphronemus gouramy). Prosiding Seminar Hasil Penelitian Terbaik. hlm. 51-62.

Tizard, I.R. (2004). Veterinary immunology: An introduction. $7^{\text {th }}$ ed. United State of America (US). Elsevier, $494 \mathrm{pp}$.

Thom, M.L., McAulay, M., Vordermeier, H.M., Clifford, D., Hewinson, R.G., Villareal-Ramos, B., \& Hope, J.C. (2012). Duration of immunity against Mycobacterium bovis following neonatal vaccination with bacillus calmette-Guerin Danish: significant protection against infection at 12 , but not 24 , months. Clinical and Vaccine Immunology, 19(8), 1254-1260.

Tsan, M.F., \& Gao, B. (2009). Heat shock proteins and 
immune system. Journal of Leucocyte Biology, 85, 905-910.

Wibawan, I.W.T., \& Soejoedono, R.D. (2013). Intisari imunologi medis. Fakultas Kedokteran Hewan IPB. Bogor (ID), 157 pp.

Wolf, J.C., \& Wolfe, M.J. (2005). A brief overview of nonneoplastic hepatic toxicity in fish. Toxicologic Pathology, 33, 75-85.
Zanoni, R.G., Florio, D., Fioravanti, M.L., Rossi, M., \& Prearo, M. (2008). Occurence of Mycobacterium spp. in ornamental fish in Italy. Journal of Fish Disease, 31, 433-441.

Zou, L., Wang, J., Huang, B., Xie, M., \& Li, A. (2011). MtsB, a hidrophobic membrane protein of Streptococcus iniae, is an effective subunit vaccine candidate. Vaccine, 29, 391-394. 